\title{
Antonio SORRENTINO: Zreformować reforme [Riforma della riforma]. Trans. A. ŻĄDŁO. Kielce: Wydawnictwo Jedność, 2019, 260 pp.
}

The author of the discussed book, Fr. Antonio Sorrentino (born 1940) is the presbyter of the Archdiocese of Salerno-Campagna-Acerno, who for many years has been in charge of liturgical affairs. He is also a research fellow at the Istituto Teologico Salernitano and an Archbishop's Delegate for the Pastoral Care of Permanent Deacons. In 2019, the Polish edition of his Riforma della riforma (translated by Fr. Andrzej Żądło) was published by Wydawnictwo Jedność in Kielce. The reflections of a long-time pastor, liturgist, and lecturer, based on solid historical and theological research, are especially important and useful for the modern Church which still has to deepen the understanding of the liturgy and take care of the beauty of its celebration.

This publication fits into the widespread debate among Catholic groups over the character of the liturgy, especially of the Eucharist and the ways of its celebration. ${ }^{1}$ A lively dispute between the supporters of Paul VI's renewal of the form of the mass and of the extraordinary form of the Roman rite (so-called Tridentine mass) causes a lot of confusion among Catholics. Many of them do not avoid discussions and clear opin-

1 "Of course the postulates that stand at the starting point of the probable changes, for example the care for the attitude of worship, the central position of the Cross at the altar and in the prayers of the people, are right. Only then these goals can be achieved without changes in the ritual itself. There are many groups in which the post-conciliar liturgy is explicitly centered on the Christ [...]. The controversy over the form of the liturgy is actually minor. It is more important that we understand the purpose of our faith [...]." T. KwIECIEŃ: Światyni nie dojrzałem, https://opoka.org.pl/biblioteka/P/PR /tp2010-06-liturgia.html (accessed: 14.12.2019), translation mine - P.S. 
ions even though they lack appropriate knowledge, both liturgical and historical. It seems that those are the supporters of the pre-conciliar most harsh in their judgments which also applies to the clergy. This includes: accusations of the destruction of the liturgy and liturgical tradition, of acceptance of Protestant influence and of Novus Ordo being responsible for the crisis of the Church since the 1970s. Unfair as it is, the voice is loud. Thus, a proper study of dogmatic theology, especially of ecclesiology and theology of the liturgy and basing the discussion on historical studies are necessary. Only then is creative conversation possible and the Church itself can recognise the proper understanding of the Eucharist.

The publication of Fr. Antonio Sorrentino fits into this discussion. Thanks to its simple form and to the factuality of arguments presented, it can lead to proper formation of the spiritual and the lay. The author notes "by persistently and wholly accepting the straightforward faith and honest love towards the Church of all members of the debate, I really tried to listen carefully to different opinions and understand their points [...] in hope that $[. .$.$] the discord should pass and that much needed accord$ should begin, brightening up the life of our communities."2 Such a goal proves the meaning of the publication which did not take the form of a violent dispute but of a calm dialogue by being focused on facts and trying to understand the thoughts of each party. At the same time, one can notice a great love for the Church and the ecclesiastical realism which prevents the author from unrealistic statements that are often heard in heated debates about the liturgy.

The value of the book was also appreciated in the Recommendation (pp. 10-12) by Archbishop Piero Marini, the Chairman of the Papal Committee for International Eucharistic Congresses and a former Master of Pontifical Liturgical Ceremonies. Archbishop Marini lists the many values of the edition: well-documented facts, an understanding of feelings and tensions in interpersonal relations, visible scientific and pastoral experience of the author, proper description of the points of both sides of the discussion and its theological profoundness. Similar recommendation is given in the Preface (pp. 13-14) by the retired Archbishop of Salerno Luigi Moretti, who emphasises the fact that the Liturgy is celebrated in a given cultural and ecclesiastical context, which makes cancelling the reform impossible. If one takes this into account, the book will aid them in discovering the Church as a communion of faith and as an ecclesiological model which expresses an understanding of liturgy and the way in which it is performed. The same is noted by Fr. Andrzej Żądło, the trans-

${ }^{2}$ Polish edition of Riforma della riforma, trans. A. ŻąDŁo. Kielce 2019, p. 15. All the following in-text quotations are from this edition. 
lator of the Polish edition of the book and a member of the Faculty of Theology of the University of Silesia in Katowice who wrote the Preface to the Polish edition (pp. 5-9). He drew attention to the historical placement of the dispute over the form of the Roman Rite, especially to how long the liturgical reform had been awaited.

The work of Fr. Sorrentino starts with the Introduction (pp. 15-16) which describes the purpose of the publication: to present appropriate arguments for pastors and persons involved in pastoral care, based on listening to various voices in the dispute. The book is concluded with a bibliography (pp. 255-257). The content itself is divided into six parts (chapters).

The first of them, "Extraordinary time for liturgy" (pp. 17-48), describes the historical context of the Second Vatican Council and the expectation of necessary reforms including those of liturgy that culminated in the liturgical reform carried out by Paul VI. The Pope gave an explicit message that only a new order prepared by capable people would be justified. Not without significance was also the atmosphere around the reform, that is, the great enthusiasm and, at the same time, the resistance of some environments.

The objections towards the reform are described in the second chapter entitled "Painful experiences of the Lefebvrites" (pp. 42-48). The author presents the peculiar extremism of Archbishop Marcel Lefebvre's supporters which can be observed in their statement that the Novus Ordo expresses a new faith, a new Church and a detachment from past centuries. The essence of the case is thus objecting to the teachings of the Second Vatican Council. As a result, the Society of Saint Pius X and people around them are not open for a dialogue that would respect the direction set by the Council, despite John Paul II and Benedict XVI's attempts to reach a compromise.

Taking into account the variety of opinions on the matter, the third part called "Revisionists' way of thinking" (pp. 50-67) is very important. Fr. Sorrentino shows the mentality of Catholics who are in communion with the Holy See but are focused on the Tridentine Rite. They express concerns about the reform arguing that it interrupts continuity, lacks transparency, is influenced by Protestantism, lacks the feeling of sacrum and mystery, emphasises the priesthood of all believers, encourages too much spontaneity and disintegrates the liturgical unity of the entire Church. At the same time, it is necessary to keep in mind the heterogeneity of attitudes (Joseph Ratzinger, Nicola Bux, Mauro Gagliardi).

Part four, "Some views and positions of the traditionalists" (pp. 70 -194) — is the most complex and interesting part of the book. It presents ten main issues raised by the traditionalists: anthropological orien- 
tation (too much focus on the person), incomplete reference to the Tradition, loss of the meaning of mystery in the new liturgy, the need for return to the Latin language and Gregorian singing, misunderstanding of the conciliar idea of "active participation," which should be conscious, pious, and active, the tension between ritualism and creativity, fears about the loss of the sacrificial character of the Holy Mass for the benefit of understanding it as a feast, objection to the location of the altar and the celebrant, postulate of the Eucharist ad orientem and decentralisation of the tabernacle. Antonio Sorrentino not only presents the views of the traditionalists, but leads a discussion based on historical and theological arguments rooted in a deep understanding of the Church. And although he supports the reform, he also points challenges for putting the beauty of the liturgy on the higher level.

To start a dialogue with groups with different opinion on liturgy, the fifth part of the book “'No' to radical solutions is important” (pp. 196229), is dedicated to reconciliation through the rediscovery and actual use of the Roman Canon and other Eucharistic prayers, use of various vestments and respect for the various forms of receiving of the Holy Communion (on the tongue and on the hand). This underlines the richness of the Church, of its experiences and of various forms of expressing one faith. ${ }^{3}$

"Promoting a peaceful dialogue" is the last chapter of Antonio Sorentino's book (pp. 232-254). Therein the author presents various attempts to reduce the tensions emerging between the "old" and the "new." The basic suggestion is to move away from juxtaposing forms of celebration. However, one also cannot give up on mentioning the advantages of Paul VI's missal that appreciates the Word of God and the meaning of the congregation of the faithful. The missal is also based on the teachings of the Second Vatican Council, especially in the area of ecclesiology. One must, however, take care of the proper celebration of the Eucharist. Fr. Sorrentino expresses this need aptly: "It is necessary for us to bring the wise reform of liturgy and its reasonable execution into abundant fruition in the Christian life and ecclesial communion."

Comprehensively, it can be said that the publication presented is in line with expectations to find the right theological and liturgical reinforcement in the ongoing discussions about the form of the liturgy and the legitimacy of the reform fifty years ago. The value of the text has

3 "If we consider the bimillennial history of God's Church, guided by the wisdom of the Holy Spirit, we can gratefully admire the orderly development of the ritual forms in which we commemorate the event of our salvation." Benedict XVI: Post-Synodal Apostolic Exhortation "Sacramentum Caritatis", 3.

${ }^{4}$ Ibidem, p. 254. 
its source in its calm tone and in its accuracy of using historical, theological, and pastoral arguments which makes reading interesting. Then, the author's experience in both scientific research and pastoral tasks in a parish (pastor) and in the archdiocese (membership in its bodies, especially those responsible for liturgy) is also helpful. That is how the book becomes a help in a scientific reflection over the topic and an inspiration for further research. It will also be helpful for pastors as a help in liturgical formation - both their own and of the faithful.

Fr. Sorrentino's publication is also important for the understanding of the Catholic intra-Church dispute between the supporters of Paul VI's liturgical reform and the Lefebvrites along with the widely understood group of traditionalists. The book states clearly the essence of the dispute which is not about the language of rituals but about the understanding of the Church which is fully completed during the celebration of the Eucharist. The concept of the People of God and the Church as a communion $^{5}$ made explicit by the Second Vatican Council naturally leads to the necessity of the long-awaited reforms and implementation of the idea of "active participation." 6

To sum up, the Reforming the Reform has one more important quality. Fr. Sorrentino's methods and the tone of the book can become an example of how difficult disputes should be carried out, even if a dialogue seems impossible. Love of the Church, desire of truth and respect towards the opponent should always be its foundation.

5 "All men are called to belong to the new people of God. Wherefore this people, while remaining one and only one, is to be spread throughout the whole world and must exist in all ages [...]. All the faithful, scattered though they be throughout the world, are in communion with each other in the Holy Spirit [...]." Second Vatican Council: Dogmatic Constitution on the Church "Lumen Gentium", 13.

6 "Mother Church earnestly desires that all the faithful should be led to that fully conscious, and active participation in liturgical celebrations which is demanded by the very nature of the liturgy [...]. In the restoration and promotion of the sacred liturgy, this full and active participation by all the people is the aim to be considered before all else." Second Vatican Council: Constitution on the Sacred Liturgy "Sacrosanctum Concilium", 14. 